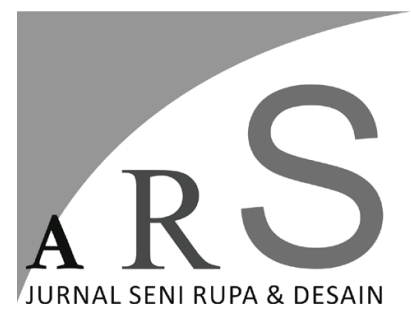

Volume 21 Nomor 3,

Desember 2018

\section{INDONESIAN CRAFT IN THE WORLD TRADE}

\author{
Timbul Raharjo \\ Jurusan Tata Kelola Seni \\ Fakultas Seni Rupa, Institut Seni Indonesia Yogyakarta \\ E-mail: timbulksg@yahoo.com
}

\title{
ABSTRAK
}

Beberapa pameran Internasional produk seni kriya selalu berzona home accessories, gift, maupun di area furniture. Pameran itu bertujuan untuk meberikan branding produk kriya pada market nasional maupun internasional (JIFFINA, 2016). Di beberapa Negara tujuan eksport maupun produsen kriya komodite ekspor Indonesia masih memiliki karakter tersendiri dan diminati para konsumen manca negara. Kegiatan promosi di Asia mengikuti pameran besar Canton Fair di Guangzhou International Convention \& Exhibition Center China, salah satu pameran terbesar yang menjadi kunjungan buyer pada putaran pameran di Asia termasuk Asia Tenggara. Dalam setahun putaran pameran Asia bermuara di Guangzho bulan Maret dan Oktober di Shanghai. Pameran ini dikunjungi para importer dari Eropa, Amerika, Afrika, Timur Tengah, Australia, dan lainnya, mereka datang belanja produk kriya dari Asia. Penyelenggaraan pameran di beberapa negara dilaksanakan dengan waktu yang saling berhimpitan dengan tujuan sebagai strategi menjaring importers saat mereka mampir di Asia Tenggara. Waktu putaran itu adalah musim pemesanan dalam persiapan materi seni kriya untuk penjualan retail maupun projek. Kesempatan itulah di Indonesia dimanfaatkan dua pameran besar yakni Indonesia International Furniture Expo (IFEX) di Jakarta dan Jogja International Furniture \& Craft Fair (JIFFINA) di Yogyakarta.

Kata Kunci: perdagangan, produk, seni kriya

\begin{abstract}
Some international craft exhibitions focus on home accessories, gifts, and furniture. The exhibitions aim at branding craft products at the national and international market, for example 2016 JIFFINA exhibition. Craft comodity from Indonesia still maintain market share in several export destination countries because Indonesian products offer special characteristics and moreover, Indonesian exporters are enthusiastic in promoting the products in international exhibitions. In Asia level, Canton Fair held in Guangzhou International Convention \& Exhibition Center China is one of the biggest programs where a big number of buyers look for products they want to purchase. In Asia, a year exhibition series peaks in Guangzhou in March and in Shanghai in October. These exhibitions are visited by importers from Europe, America, Africa, The Middle East, Australia, etc. They come to buy Asian furniture. Some exhibitions in several countries are intentionally organized within a short time in sequence to grab buyers coming to South East Asian area. It is when they commission products from Indonesian producers, in form of retails or projects. Indonesian stakeholders respond this opportunity by organizing two big exhibitions, namely Indonesia Ibternational Furniture Expo (IFEX) in Jakarta anf Jogja International Furniture and Craft Fair (JIFFINA) in Yogyakarta
\end{abstract}

Keywords: trade, product, craft 


\section{Background}

Craft grows as a branch of art science giving a great chance to explore traditional arts which develop as trading commodities having Indonesian cultural values. The influence of craft values on third world society is an important issue in humanities. The craft role becomes more effective in increasing society economy as a contributor and developer in research activities and can be utilized by experts in deepening craft new ideas and designs. Important issues in craft are always connected to international issues, such as the raw material use, especially timber in forest conservation, trade fear, eco labeling, alignments and other issues. It should be realized that in the international world, Indonesian craft products must be developed continuously so the potential material and Indonesian culture can be maximally explored without leaving the existing cultural traditions. Because of the competitive world trade, the government and the craft businessmen are trying to synergize like two sides of a coin. Both of them help each other but on the other hand the existence of new regulations give the setback implications in other fields and often inhibits its performance.

In the world trade constellation, there is no denying that the craft is one of the commodities giving a significant economic growth value in Indonesia exports. Most of the craft business start from home industries carried out by family members as Micro, Small and Medium Enterprises, then become a Small and Medium Enterprises and then become a modern craft company, using local materials and workers to participate in global trade and have great opportunity in it. (Sri Sultan HB X, 2016) The government is targeting the export in 2017 with an export value of US $\$ 1.9$ billion even though the president of the Republic of Indonesia expects to reach US $\$ 5$ billion in his office term until 2019. The work has been started although if faces the domestic regulation synchronization issue. It must be solved due to Southeast Asian products competition positioning Indonesia below Vietnam and Malaysia. For example, craft furniture and craft products occupy the 13rd rank among furniture and handicrafts exporter countries. The furniture and handicraft total export reached 124 billion US dollars globally.
While Indonesian furniture exports only reached 1.5 percent of the total, only US $\$ 1.9$ billion. The position of Vietnamese furniture exports can reach around US $\$ 4.2$ billion. Malaysia, which has smaller human resources (HR) and natural resources (SDA) than Indonesia, is able to export furniture at US \$ 2.4 billion (Antara News 2014). However, the upcoming efforts to achieve US \$ 2.4 billion in 2019 and US $\$ 5$ billion in 2020 the 2019 and 2020 targets, by improving the material and machinery assistance (Bisnis.com, 2017). It is overlap to achieve the future vision to increase export value to US $\$ 5$ billion.

\section{Craft Communication Method}

The author both as a discourse and a practitioner has good relation experience in the craft world. At least the craft understanding is always oriented in developing Indonesia's local potential in global. Efforts are taken to give benefits for both science and society welfare. Knowledge mastery is important in making practical relations. It raises belief among the relations, especially in the craft trade. There are two different sides when the author thinks the craft trade becomes very rigid with a definite production cost because there is a calculation of profit and loss, but when speaking of aesthetics, craft is the benchmark for artistic values in the content of concepts and forms. There are two trading activities, economic and artistic activities in the craft business. Indeed, both are relatively difficult to put together, but actually they can work together if they give each other portions. A craftsman does not only make the craft, but he must also think about selling his creativity to make new breakthroughs and innovation in its development. (Program, 2014) Creative work with reproductive work, creative work is categorized as research and product development work, as creative concepts in accordance with the world development and technical understanding of reproductive work. For the author, both are equally important because there is a proverb "can make but can't sell, can sell but can't make" Whereas, Indonesia export-import activities are growing, and the craft export potential has good prospects. It requires government assistance and stakeholders to encourage the craft export such as business activities 'freight forwarding' to support 
the ease and the flow in international trade. It requires adequate transportation facilities in accordance with the export goods or commodities (Yunianto, 2011). Many new cargo companies facilitate craft entrepreneurs to carry out export activities. For small entrepreneurs who have not been able to export themselves, they need to collaborate with the brewers. They will export using consolidated products from many suppliers, though craft products are export commodities but the craftsman does not export by themselves. The domestic cargo company will handle the export.

To fulfill export quality, it must be understood that the craft distributed to foreign countries has different cultural and natural conditions. To fulfill the accepted standard, the craft must meet the standardization from the destination countries. The material quality must be durable and not damage due to weather changes, good packaging providing safety for craft products. Like master inner packaging technique, wooden boxes, and the culture suitability whether the craft products can be accepted in the Middle East, Europa, and so on. The export documents for craft are increasingly complicated, mainly wooden products, including furniture. The Verification and Legality Timber System (SVLK) is a system designed to verify the legality of the wooden products in Indonesia. Designed to fight illegal logging and improve forest management throughout the world. The document is one of the export documents that has not been widely owned by the exporters.

The craft world trade activities are inseparable from creativity, production, market, protection, and entrepreneurship. The theory is usually used by the author to dissect the business world, especially in the writer's field. (Raharjo, 2014). It provides guidance about craft business into the export field. The creative aspects impact on creativity development in new product production in the market demand. The creativity must be based on the society needs and tendencies. A craftsman must think deeply to determine what new products will be created, so the product will go globally and be able to combine between craft and design and even with pure art. (Risatti, 1943). It is used to position the individual craftsman creativity. The idea is used as the basis for the new craft creation mixed with the sustainable in production process. If the new craft is accepted well by the market, the material availability, the ease technique, and its distribution must be considered well.

The craft communication path trade is always linked to craftwork, it is understandable, because craft is embryos of craft art. Creativity doesn't not always depend on one thing, creativity will be more developed and wild when finding new things in its creation. The craft is sometimes presenting its high uniqueness so it is sold limitedly or even exclusive. Some world brands often produce limited edition craft products. The communication path must be used as a place to give great chance to the craft development so it gives welfare to the craftsman.

\section{World Market Path}

In international trade, it is often called craft as a result from craft reproduction prioritizing the creation process, even furniture is a part of craft products requiring a deep thinking concept. The dominant products appearing in woodcraft businesses is furniture. The efforts form Indonesian craftsmen alliances for example furniture and craft associations. The association doubles both as a political part of the organization to voice and develop furniture and handicraft businesses and as a communication tool to carry out furniture and craft business relations with the government and foreign cooperation. One of the beneficial acts is opening market opportunities in Indonesia to participate and hold international furniture and craft exhibitions as well as the development policies of the association. It also happens in organization naming, furniture and craft association abbreviated as Himki, Asmindo, and Amkri, all three are Indonesian furniture and craft associations. Each Indonesian furniture and craft association is a tool to gather the furniture and craft entrepreneurs, but sometimes the number of associations makes an obstacle. The association cooperates with the government and engages in many joint development activities, such as exhibitions, coaching, facilitation, etc.

In managing the market, information technology is used to simplify and expand 
markets, mainly in cyberspace. Businessmen who intentionally create a website, blog, or an account at Facebook and Twitter to promote their products. This progress is very useful to serve as one of the business strategies. However, products displayed via cyberspace are sometimes have different display from the original ones. That's why product exhibitions are always visited by customers because they can see the real product quality directly, because the soul of buyers can easily determine transactions by looking at the products directly. Number of buyers mostly come from Europe, America and Australia, then Latin America, the Middle East, Africa, Korea and Japan, although not so significant. They have different product character trends. European countries have a wider market for Indonesian craft products. Government and entrepreneurs are participating in the exhibition events to maximize the trade, such as:

\section{Ambiente Frankfurt Germany}

This exhibition is one of the important furniture and craft exhibitions visited by European retailers. This exhibition takes place in Frankfurt every February. Ambiente becomes the main platform in business system order, presenting craft products mainly furniture specifications (tables, chairs, beds, furniture, decorations, etc. Also offering custom products for hotel furniture and accessories, restaurants / cafes, office buildings, cruise ship, also in the form of a contract project. Indoor and outdoor products are exhibited in various products. Visitors get a big opportunity to exchange ideas and experiences with exhibitors from around the world, experts such as craftsmen, architects, and designers. Special presentations are given in Ambiente, the appreciations are for the creativity in working according to world trends ("https://ambiente.messefrankfurt.com/ frankfurt/en.html," nd)

\section{Maison \& Objet Paris}

This exhibition is quite practical in Paris, France, the products shown have their own creativity for the consumption of the European community, is the main trade show in France for interior design. Showing the world's best designs, known having many world-level designers.
The exhibition is held twice a year, bringing consumers meet with world-renowned designers. Offering innovative collections and talented craftsmen or designers in one place. Maison \& Objet in Paris is a great place for household items and decorations. At present, this exhibition shows various products of household appliances and decorative items from exhibitors. This exhibition is a communication and information platform in the industry offering opportunities for exhibition companies throughout the world. Visitors can learn detailed and comprehensive information about the latest trends and products in the industry. ("Http://www.maison-objet.com/ en/paris," n.d)

\section{High Point Market USA}

The biggest furniture and craft international exhibition in America offers home furnishings markets, showing various innovations in the field of interior design and home decoration. Held in the federal state of North Carolina in the United States, this exhibition is specifically for the American market and the surrounding area, presents new furniture products and crafts. Latest furniture design products from all over the world. New exhibitors also use High Point Market to increase their popularity. This exhibition is a good valued placed on high-quality furniture. Young designers and buyers use the furniture and craft markets in the international market field. ("Https://www.tradefairdates.com/High-PointMarket," n.d)

\section{IFEX Jakarta}

The largest exhibition in Indonesia shows furniture and handicraft products, indoor and outdoor furniture. Held at the Jakarta International Expo Kemayoran Jakarta every March. The exhibition displays native Indonesian products. Its success from year to year confirms the increasing strength and popularity of Indonesian furniture in the global market and has been designated as a major exhibition event. Indonesia International Furniture Expo is an Indonesian flagship event and international showcase for the furniture and craft industry. This is strongly supported by furniture and craft industry players and the Indonesian 
government, because it is known as one of the leading furniture exhibitions in Southeast Asia. This exhibition attracts thousands of professional buyers, considered as one of the furniture $\& \mathrm{craft}$ events that must be attended by importers from Europe, America, Australia and others. ("Https:// www.eventseye.com/fairs/f-ifex-(indonesiainternational-furniture-expo," n.d)

\section{JIFFINA Yogyakarta}

The author is one of the owners of the international furniture $\&$ craft fair exhibition (JIFFINA), as chairman of the JIFFINA JavaBali forum. The exhibition is held every year. The stands, buyer handling, exhibitors, artistic, and promotion are designed in international standard. A significant increase occurs every year, the committee always invites buyers from overseas, nearly 20,000 buyers throughout the world. JIFFINA is the largest International Furniture \& Craft exhibition in the Region of Yogyakarta as the venue for this event. JIFFINA is held every March as many buyers from Europe, America, Australia, and other countries are conducting business visit to Asia, and have an agenda in Southeast Asia. The moment is captured. JIFFINA has a great potential for material resources and labor specifically furniture and crafts. Yogyakarta, Central Java and East Java regions which become furniture and handicraft MSME centers in Indonesia. It is believed that the JIFFINA exhibition will be the biggest furniture and craft UMKM exhibition in Indonesia in the future (JIFFINA, 2017).

\section{Production Dynamics and Distribution}

Once mentioned above, the terms of crafts and handicraft often make us confused, so as not to misunderstand, it can be explained that the craft is a product of art created by craftsmen through the creation methods by exploring concepts and forms. While handicraft, it is produced in number and has an economic value. (Indonesia, 2015) The creativity can emerge from craftsmen by making new craft creations. New craft products emerge from creative and purposive artists. These objectives can be both individual and other considerations such as social or economic, related to the market.
Crafting centers grew naturally. The craft potential in the craft center spread throughout Indonesia including Jepara wood carving and furniture, Cirebon rattan furniture, Serenan Klaten furniture, Trangsang Sukoharjo, bamboo Tasikmalaya, Magetan leather, Pasuruan furniture, batik Pekalongan, Blora Teak roots, Kasongan ceramics, and so on. The centers have been exporting their products to overseas. They experience up down phase in export MSME activities. In general, they utilize both manual work skills and intensive labor. It should be realized that Indonesian craft is highly valued because it is handmade and has human values. So if they get a lot of orders, the reproduction method is increasing the number of labor. Indeed, it is realized that hand-made size shape stability has resistance due to the different skill level and perseverance and tidiness of each worker. It is required Quality Control (QC) which is responsible for maintaining the quality of the craft products.

Export matters are more complicated compared to domestic sales, the largest foreign markets are distributed through export procedures. The rules and regulations in each export destination country bring consequences for craft commodities to meet export quality standards. These regulations are written at export documents in the form of fumigation certificates, Bill of Leading (BL), Certificate of Original (COO), Invoice Packing List, and ISPM \# 15, SVLK, and so on. The buyer must receive the documents before the container arrives at the destination port. In addition, the quality of craft covers material quality, workmanship, and time delivery must become the priority. Several aspects such as cultural diversity, seasons / weather, and developing trends in overseas must be considered due to the different condition from Indonesia. Thus, various aspects related to the quality of the commodity must be calculated in marketing the product. (Raharjo, 2017)

The export procedure is more complex than the import procedure where the rules are more numerous and complicated. In import activities almost all goods are subject to import duties and other import taxes, while in export activities more goods that are not subject to export tax 
or export tax, timber and rattan are subject to export duties, export taxes, and so on. ("Http:// hsh.co.id/prosedur-dan-tata-cara-ekspor," nd) Import constraints often happen when supporting materials in the craft manufacture are not provided in the country such as supporting materials, furniture accessory components, electrical, etc. It starts when the exporter prepares the goods starting from the production process, packaging, stuffing, and complete documents for container loading until the goods are sent. After the goods and the ship schedule are ready, the exporter can submit a custom document known as Notification of Export Goods (PEB). PEB contains exported goods data, including exporter data, goods recipient data, customs data, brokers and so on. Then deciding the ship transport to the destination country, item details, such as the number and type of goods, accompanying documents, and the number of containers used. There are many internal and external policies which of course must be considered so that the container does not face obstacles to its destination.

\section{Closing}

Craft business activities are carried out in coordinated quantities in the form of export activities. The craft commodities has reached foreign countries, the Netherlands, Italy, Spain, France, Australia, Canada and the Caribbean countries. These countries are potential world markets as decisive countries in the globalization era. The selling product activities to the global market are linked with the world trade rules. The globalization era has become a reality experienced by many countries, companies, communities, and individuals in all parts of the world. Of course they agreed to regulate the commitment of how to make the world trade process better and organized, then the World Trade Organization (WTO) emerged. The rules for free trade have logical consequences for every country to protect themselves from various kinds of changes indicating danger to domestic trade activities in each country, even to the danger to the environment such as the spread of disease. Therefore, there is a supra-state agreement making provisions and rules so as to create trade zones such as the Asia Pacific Economic Cooperation
(APEC), General Agreement on Tariff and Trade (GATT), and others. Therefore, in making products that are specifically for export, they must meet the standards so the products can be accepted by the export destination country or the relevant market. The craftsmen are required to understand the causes and conditions that might arise. So, the craftsmen must maintain the craft quality sold to overseas. Like the rules about packaging standards that might contain harmful disease. Canada and Australia are very strict with the rules of fumigation, namely the International Standard Pycosanitary Measure (ISPM \# 15).

That's all about the craft economic constellation world. Hopefully it is useful, please apologize for the mistake.

\section{Bibliography}

Indonesia, K. P. dan E. K. R. (2015). Ekonomi Kreatif: Rencana Aksi Jangka Menengah 20152019.

Programme, A.-R. C. L. E. (2014). Present and Future of Asean Craft. Seoul.

Raharjo, T. (2014). Creative Batik Motif Design Based on Local Cultural Art and Natural, Environments. China USA Journal, 13(1).

Raharjo, T. (2017). Potensi, Permasalahan, dan Peluang Kriya Indonesia sebagai sub-sector dalam pengembangan Ekonomi Kreatif. Yogyakarta.

Risatti, H. (1943). A Theory Of Craft: Function And Aesthetic Expression. Chapel Hill: The University pf North Carolina Press.

Sri Sultan HB X. (2016). Sambutan pembukaan Jiffina. Jiffina.

Yunianto, B. (2011). Proses Penanganan Ekspor Barang General Cargo (Genco) melalui Udara pada PT. Internusa Hasta Buana Branch Solo. Universitas Sebelas Maret.

http://hsh.co.id/prosedur-dan-tata-cara-ekspor. (n.d.).

http://www.maison-objet.com/en/paris. (n.d.).

https://ambiente.messefrankfurt.com/frankfurt/ en.html. (n.d.).

https://www.eventseye.com/fairs/f-ifex(indonesia-international-furniture-expo. (n.d.).

https://www.tradefairdates.com/High-PointMarket. (n.d.). 